\title{
Boys Will Be Boys? Subverting Traditional Power Structures in Asian-American Prose
}

\author{
Ines E. Veauthier \\ Johannes Gutenberg University of Mainz, Germany; An der Hochschule 2, D-76726 Germersheim \\ *Corresponding Author: veauthie@uni-mainz.de
}

Copyright $(0) 2013$ Horizon Research Publishing All rights reserved.

\begin{abstract}
Leaving one's home country behind and starting a new life on a different continent may also involve being confronted with behaviors and values completely different from the ones that were deemed the only ones back home. This experience is described by the protagonist of the Asian-American author Amy Tan's story "The Red Candle", recalling her arrival in California from a small village in China. In her attempt to bridge the gap between the conflicting worlds of "Old East and New West", the protagonist uses concepts and metaphors that might be transferred and prove valuable in more than one cultural context. In the hierarchy of the culture which is described, a position of power is most of all connected to gender, age, health and wealth. The analysis will show the subtle ways in which these criteria are interconnected and in which their importance and meaning are both subject to negotiation and to possible change over time.
\end{abstract}

Keywords Power Structures, Cultural Constructs, Discursive Negotiation, Gender, Subversion

\section{Introduction}

Amy Tan's story “The Red Candle" tells us about a girl in China who is promised in marriage at two and at twelve goes to live with her fiancé's family. The wedding takes place when she is sixteen, yet the girl can later free herself without breaking the promise her parents gave. An analysis of health and power structures in this story might be expected to consider medical or biological as well as sociological aspects of human life to determine the dynamics of their connections. According to Antonio Gramsci [1], a very general view of the defining factors of human interaction focuses not on the seemingly natural elements but on the concepts and ideas that people feel will characterize their lives and relationships:

Philosophy cannot be reduced to a naturalistic "anthropology": the nature of the human species is not given by the "biological" nature of man.
The differences in man which count in history are not the biological - race, shape of the cranium, colour of skin, etc. [...] It is not "thought" but what people really think that unites or differentiates mankind. [1]

In order to show that biological factors may indeed take second place, the analysis of the story "The Red Candle" will demonstrate in what way people's thinking can be negotiated, with the effect of changing the accepted power structures. This will, for example, be demonstrated by overriding traditional notions of the biological rules of childbearing, thus even allowing for a woman's pregnancy to be effected in a completely discursive manner.

\section{Analysis}

The causes for a woman's pregnancy may usually be attributed to the realm of masculine power, and most certainly so if the setting is a rural area in China in the early decades of the $20^{\text {th }}$ century. The protagonist of "The Red Candle" describes her home town Taiyuan as a backward place in the country (Tan 44). Taiyuan is situated in the north of China, with Beijing to the northeast of it. When the protagonist is just a toddler, she is promised in marriage to the Huang family's baby son. At the age of twelve she has to leave her family to live with the Huangs and the marriage takes place four years later, when she has just turned sixteen. By this time, the "Japanese were in every corner of China" (Tan 51). Historians generally define the years from 1937 to 1945 as the height of the conflicts between China and Japan. 1 It can therefore be assumed that the events

1 The Faculty of History at the University of Oxford has started a research project examining not only the war between China and Japan but also the consequences and implications for the contemporary situation: "The Second World War in China was the single most wrenching event in modern Chinese history. The conflict is often termed the second Sino-Japanese War, and known in China as the War of Resistance to Japan. There are arguments that the conflict began with the invasion of Manchuria in 1931, but between 1937 and 1945, China and Japan were at total war. When Japan was finally defeated in 1945, China was on the winning side, but lay devastated, having suffered some 15 million deaths, massive destruction of industrial infrastructure and agricultural production, and the shattering of the tentative modernization begun by the Nationalist government." [2] 
described in "The Red Candle" take place during the late 1930s. Such a traditional community would define procreating as proof of a man's health, connecting health, power, and masculinity not only in a bind, but moreover in a logical association.

According to Confucian thought, the lives and acts of people are governed by five different types of relationships. In this system, a woman is always seen in a subordinate position, following the instructions of the men she is related to [3]. However, for those in a dominating position, the system of prescribed relationships includes as well the obligation to look after those who are subordinate to you [4]. Since these principles are to be understood within the framework of the Confucian idea of predestination, the five different relationships and one's own position within the system only serve to understand one's fate and one's call which are seen as one's very own divine mission [5].

In effect this means that a man's place is at the top of the hierarchy; while his health and power are never at stake, they are not even considered ever to be questioned precisely because masculinity is understood to be a synonym of power and health. This again is an approach to be found not merely in this backwards community, but rather it is also an established Western concept to combine masculinity and superiority into a natural must: "Since men have held the great predominance of power over the last two centuries, one inevitably studies male domination in studying recent gender history" [6].

Coming back to the protagonist's husband, it is evident that he is looked upon as a particularly powerful member of the family which is explicitly expressed in his name, "Tyan-yu", where "Tyan means sky because he was so important" (Tan 44). He likes throwing his weight about acting "like a big warlord" (Tan 50), complaining and nagging with the express purpose of making the protagonist's life miserable (Tan 50). Since the protagonist is forced to live according to the rules of her society, she cannot risk any disobedience but must adapt to her circumstances. She resolves to work so hard that the physical exhaustion leaves no room for feelings like sadness or rebellion until she comes to see Tyan-yu as much more than just the sky, namely as a divine being "a god, someone whose opinions were worth much more than my own life" (Tan 51), as she expresses it.

At a closer look, the protagonist's husband proves to be controlled by fear instead of exerting real power. This is most clearly noticeable to the protagonist when she finds out that despite his hypermasculine acting, he is too scared to look at a naked woman, let alone get into closer contact with his own wife (Tan 58). However, without any sexual contact between the spouses it proves a great challenge for the protagonist to reach the desired condition of pregnancy since he "would never touch" her (Tan 58), as she delicately phrases it.

The young man's fear of yet another woman representing the true power structures proves to be at least as great as his fear of physical female closeness. Yet his male integrity as a metaphor of health and power would never be openly challenged because of the hierarchical structure of the society described. Tyan-yu is afraid of his mother and her claim to ancestral protection which will be examined in the next step, but since he cannot bring himself to touch his wife he simply relies on his absolute male superiority and tells his mother lies about his wife (Tan 57).

In this hierarchical system, a woman's position is defined by her attachment to a male member of society, as can be seen when looking at the protagonist and her environment. Thus, it is up to the mother of a husband-to-be to choose her daughter-in-law, guided by a matchmaker (Tan 43-45), representing yet another position of female power. According to Tayuanese customs and rules of the time, Huang Taitai, the protagonist's future mother-in-law, is in a very powerful position which she has acquired mostly due to her age. A woman's power may thus supersede a man's yet this outward incongruence does not challenge the male-dominated power structures as such since at a closer look, this power is more of a burden and another opportunity to be blamed should anything go wrong.

Finding the right daughter-in-law is a task to be performed not only in a woman's own personal interest, but is a two-fold investment. On the one hand, it is meant to be a kind of insurance for the husband's parents and their situation once they are old and defenceless. On the other hand, all the ancestors of the family depend on this choice as well because it is the duty of a daughter-in-law to protect past generations against oblivion by honouring the traditions and by producing a male descendant: "We were told stories of sons who were so influenced by bad wives that they threw their old, crying parents out into the street. So Taiyuanese mothers continued to choose their daughters-in-law, ones who would raise proper sons, care for the old people, and faithfully sweep the family burial grounds long after the old ladies had gone to their graves" (Tan 45). This example illustrates the authenticity of the characters in this short story whose behavior is true to the traditions of Chinese society in which honor and respect for one's ancestors are deeply ingrained: "Furthermore, ancestor worship has been the most universal form of religion throughout China's long history; it was the responsibility of the head of a household to see to it that sacrificial offerings to the dead were renewed constantly" [7]. The ritual of ancestor worship is based on the strong belief that dead members of the family may take an active part in the affairs of the living members and can thus be asked for assistance. This worldview which is based on the principles established by Confucius, perceives an ongoing, active communication between the living and the dead [8]. The ancestors are understood to be in close relation with the gods which enables them to help those who show the proper respect. In summary, this network of interactions may be termed "kinship values" [9].

Compared with these positions at the top of the hierarchy as either a man or at least the mother of a man, the protagonist is found at the other end of the power spectrum. When she is a little girl, she is seen as a potential 
daughter-in-law and described as an "earth horse" or "a strong horse" by the matchmaker who assures Huang Taitai that this girl would be a wise investment: "She will grow up to be a hard worker who serves you well in your old age" (Tan 44). True to this description, the protagonist is treated not like a member of the family but as a worker or servant when she comes to live with her fiancé's family: "No big celebration was held when I arrived. Huang Taitai didn't have red banners greeting me in the fancy room on the first floor. Tyan-yu was not there to greet me. Instead, Huang Taitai hurried me upstairs to the second floor and into the kitchen, which was a place where family children didn't usually go. This was a place for cooks and servants. So I knew my standing" (Tan 49).

This child of only twelve years is not considered worth anything beyond her functions as expected by the Huang family. Her status would slowly rise as soon as she could prove herself to be pregnant and again, if the desired grandson were delivered. The childless daughter-in-law would thus rise within the hierarchy by turning into the mother of a son and the next one in line for the powerful position of choosing a daughter-in-law for him. This functional view of people in general and particularly of the protagonist is also shown by her nameless state. The story is told by an I-narrator whose name is Lindo Jong, yet none of the other characters in the story ever calls Lindo by name. Therefore, the positions of power of both the husband and the mother-in-law whose names, Tyan-yu and Huang Taitai, are constantly used, are highlighted even more. Viewing individuals mainly as members of a social group, who fulfill certain roles and functions, characterizes collectivist societies and can still be observed in parts of China: "[T]he sense of self seemed largely external; you were identified by the way that others viewed you. That had always been the goal of Confucianism, which defined the individual's place strictly in relation to the people around her: she was somebody's daughter, somebody else's wife, somebody else's mother; and each role had its specific obligations. This was an excellent way to preserve social harmony [...]" [10].

On the one hand, the different terms used to refer to the protagonist express this view of a certain place within a group, e.g. when she is called "daughter" (Tan 45). On the other hand, these terms often convey an additional meaning and to give an example, a lot of hard work is required to be called "an obedient wife" (Tan 50,57). The opposite of this "title" must be avoided at all costs:

I heard her huffing and then all of a sudden [Huang Taitai] stood up from her chair, walked over to me, and slapped my face.

"Bad wife!" she cried. "If you refuse to sleep with my son, I refuse to feed you or clothe you." So that's how I knew what my husband had said to avoid his mother's anger. I was also boiling with anger, but I said nothing, remembering my promise to my parents to be an obedient wife. (Tan 57)
Struggling to reclaim the status of an obedient wife means trying to belong by avoiding a position of alterity: "'Identity' is the affirmation of who we are by contrasting nearly every element of our way of life with that of others. This self-other dialectic is the core of the debate on alterity and identity: they invest each other with meaning, one does not go without the other" [11]. The desired feeling of belonging is expressed in a term of endearment used by Huang Taitai, the mother-in-law, when she finally seems less hostile towards the protagonist: "'What's wrong, little daughter? Tell me quickly,' she cried" (Tan 60).

This same situation and the interactions of the characters can also be used to illustrate how fear subverts the power structure. Fear makes the protagonist endure her hardships since any acts of disobedience would cause her parents to lose face as her mother's farewell words strongly remind her: “'Obey your family. Do not disgrace us,' she said" (Tan 48). Fear makes the protagonist's husband hide his sexual inclinations, the discovery of which would show his lack of conformity and might destabilize his health and thus his hierarchical position:

Inasmuch as "identity" is assured through the stabilizing concepts of sex, gender, and sexuality, the very notion of "the person" is called into question by the cultural emergence of those "incoherent" or "discontinuous" gendered beings who appear to be persons but who fail to conform to the gendered norms of cultural intelligibility by which persons are defined. "Intelligible" genders are those which in some sense institute and maintain relations of coherence and continuity among sex, gender, sexual practice, and desire." [12]

This fear of the Other serves as the backdrop against which to define the desired, normal identities. For fear of losing power and of being forgotten, Huang Taitai follows the traditional custom of choosing a daughter-in-law and insisting on the speedy delivery of a grandson. Any delays are attributed to female malfunctioning because her son's status is never questioned, so "Huang Taitai flew into another kind of rage. 'My son says he's planted enough seeds for thousands of grandchildren. Where are they? It must be you are doing something wrong.' And after that she confined me to the bed so that her grandchildren's seeds would not spill out so easily" (Tan 58).

Driven by her fear of oblivion and negligence of the ancestors, Huang Taitai virtually keeps the protagonist prisoner, reducing her to her physical functionality. The young girl uses Huang Taitai's strong fear which is part of their society's belief in kinship values to subvert the whole power system. For her plan to succeed, she needs the correct timing so she chooses the "Festival of Pure Brightness" (Tan 59) since this is a special day to "think about your ancestors" and to visit their graves. This implies that Huang Taitai is particularly vulnerable because these circumstances have "special meaning to someone looking for grandsons" (Tan 
$60)$.

The subsequent message also carries special meaning since the protagonist claims it is the ancestors insisting on the marriage to be ended. Apart from some cleverly staged signs the protagonist provides the authentic and disturbing news of her husband's end of the marriage candle having been blown out by a "big wind" during their wedding night (Tan 60). Tradition says the red candle has to burn without interruption as a symbol for the marriage itself: "That candle was a marriage bond that was worth more than a Catholic promise not to divorce" (Tan 54-55). When the matchmaker's servant has to confess that the candle was indeed blown out during the wedding night, the ancestors' prophecies are not doubted any longer and the protagonist is released from her marriage in order to protect Tyan-yu's life.

Her true act of subverting the structures of health and hierarchy, however, is her manipulation of the basic laws of nature which she succeeds in by playing on her society's belief system and traditions. During her confinement she watches a little servant girl and starts negotiating her own freedom by merging the two identities: "I envied this girl, the way she could walk out the door. Sometimes as I watched her from my window, I would imagine I was that girl, standing in the courtyard [...]" (Tan 58). Telling Huang Taitai about the ancestor's acts, the protagonist is using the powers of performativity and she proves that bodies can be discursively produced, as claimed by deconstructivists who call the body a fiction or illusion [13]2:

"And finally, I saw [our ancestor] plant a seed in a servant girl's womb. He said this girl only pretends to come from a bad family. But she is really from imperial blood, and..."

I lay my head down on the pillow as if too tired to go on. Huang Taitai pushed my shoulder. "What does he say?"

"He said the servant girl is Tyan-yu's true spiritual wife. And the seed he has planted will grow into Tyan-yu's child." [...]

I had seen [the servant girl's] eyes grow bigger and her teasing voice become smaller whenever the handsome delivery man arrived. And later, I had watched her stomach grow rounder and her face become longer with fear and worry. (Tan 62)

The true biological reality of the Huang family's grandson seems irrelevant when seen in the light of spiritual powers arranging for a new type of reality. To philosophers, there is even the chance that people in general are not able to distinguish between true and false matters so that our perceived reality and the world as such may be an illusion [14]. The protagonist is able to construct her own reality this way, manipulating fact and fiction to survive on her own terms:
That "human nature" is the "complex of social relations" is the most satisfactory answer, because it includes the ideal of becoming (man "becomes", he changes continuously with the changing of social relations) and because it denies "man in general". [1]

The protagonist of "The Red Candle" illustrates how she truly uses her potential within an intricate network of social rules and relations. There is a twist, however, to this story, namely the reason why the narrator wants to tell her daughter what had happened many years ago in China: "It's too late to change you, but I'm telling you this because I worry about your baby. I worry that someday she will say, 'Thank you, Grandmother, for the gold bracelet. I'll never forget you.' But later, she will forget her promise. She will forget she had a grandmother" (Tan 42-43).

Having used her own mother-in-law's fear of oblivion, of grandchildren neglecting or forgetting their ancestors, the protagonist later experiences the same fear and anxieties. However, her approach is completely different from Huang Taitai's since she uses her story to make her family understand her past and thus feel a bond of love that lasts into the future. Comparing different cultural values, the narrator explicitly aims to show how her experience of being "brainwashed" may be transferred and prove valuable in other cultural contexts:

How much happier could I be after seeing Tyan-yu eat a whole bowl of noodles without once complaining about its taste or my looks? It's like those ladies you see on American TV these days, the ones who are so happy they have washed out a stain so the clothes look better than new.

Can you see how the Huangs almost washed their thinking into my skin? (Tan 51)

The protagonist's direct reference to commercials indicates the importance of these aspects of American popular culture. This seemingly trivial medium in fact represents commonly accepted values:

In short, the mass media constitute a forum for depicting and, to a certain extent, debating current morality. They offer the viewer situational models that can be adapted and used in the individual's own life. Far from being shallow or meaningless, popular entertainment examines what it is to be human in our society, dissecting and reconstructing the most basic social situations and providing an ongoing discussion of our very essence. [15].

The narrator thus uses her story to demonstrate the subtle ways in which power can be negotiated in any hierarchical system by taking advantage of the respective society's limitations and constructs. 


\section{Conclusion}

The examples discussed above prove the main thesis of the paper, namely the priority of discursive techniques over traditional structures of power. While the negotiation of power cannot necessarily be carried out openly, there is ample room for subverting the established system. The maxim "Boys Will Be Boys", for example, implies the predominance of gender constructs. This may be utilized as a tool to illustrate the irrationality of established categories and at the same time, to introduce changed notions of "reality".

\section{REFERENCES}

[1] Tan, Amy. "The Red Candle." The Joy Luck Club. New York: Ivy Books, 1989. 42-63.

[2] Gramsci, Antonio. Selections from the Prison Notebooks of Antonio Gramsci. Ed. and transl. by Quintin Hoare. London: Lawrence and Wishart, 1998.

[3] History at Oxford: http://www.history.ox.ac.uk/research/project/chinas-war-wit h-japan.html (accessed on 29 July 2013)

[4] Konfuzius. Gespräche des Meisters Kung (Lun Yü). Trans. Ernst Schwarz. München: Deutscher Taschenbuch Verlag, 1985.

[5] Huang, Ning. Wie Chinesen denken. Denkphilosophie, Welt- und Menschenbilder in China. München: Oldenburg, 2008.

[6] Meisig, Konrad. "Die Ethik des Konfuzius". Chinesische Religion und Philosophie. Konfuzianismus, Mohismus, Daoismus, Buddhismus. Grundlagen und Einblicke. Ed. Konrad Meisig. Wiesbaden: Harrassowitz, 2005. 1-34.

[7] Rotundo, Anthony E. American Manhood. Transformations in Masculinity from the Revolution to the Modern Era. New York: Basic Books, A Division of Harper Collins Publishers, 1993.

[8] Encyclopedia Britannica on ancestor worship in China: http:/ /www.britannica.com/EBchecked/topic/515665/sacrifice/663 22/Religions-of-China (accessed on 1 July 2013)

[9] Huang, Ning. Wie Chinesen denken. Denkphilosophie,
Welt- und Menschenbilder in China. München: Oldenburg, 2008.

[10] Yang, C. K. "Chinese Thought and Institutions". The Functional Relationship Between Confucian Thought and Chinese Religion. John K. Fairbank, ed. Chicago: U of Chicago P, 1957. 269-90.

[11] Hessler, Peter. River Town: Two Years on the Yangtze. New York: Harper Collins, 2001.

[12] Voestermans, Paul. "Alterity/Identity: a Deficient Image of Culture." Alterity, Identity, Image. Selves and Others in Society and Scholarship. Eds. Raymond Corbey and Joep Leerssen. Amsterdam: Rodopi, 1991. 219-50.

[13] Butler, Judith. Gender Trouble. Feminism and the Subversion of Identity. New York and London: Routledge, 1990.

[14] Butler, Judith. Bodies that Matter. On the Discursive Limits of "Sex". New York and London: Routledge, 1993.

[15] Duden, Barbara. "Die Frau ohne Unterleib: Zu Judith Butlers Entkörperung. Ein Zeitdokument." Feministische Studien: Kritik der Kategorie 'Geschlecht' 2 (1993): 24-33.

[16] Hirschauer, Stefan. "Dekonstruktion und Rekonstruktion. Plädoyer für die Erforschung des Bekannten." Feministische Studien: Kritik der Kategorie 'Geschlecht' 2 (1993): 55-67.

[17] Lorey, Isabell. Immer Ärger mit dem Subjekt: Theoretische und politische Konsequenzen eines juridischen Machtmodells: Judith Butler. Tübingen: Ed. Diskord, 1996.

[18] Lorey, Isabell. "Der Körper als Text und das aktuelle Selbst: Butler und Foucault." Feministische Studien: Kritik der Kategorie 'Geschlecht' 2 (1993): 10-23.

[19] Maihofer, Andrea. Geschlecht als Existenzweise: Macht, Moral, Recht und Geschlechterdifferenz. Frankfurt/Main: Helmer, 1995.

[20] Nietzsche, Friedrich. Jenseits von Gut und Böse. Vorspiel einer Philosophie der Zukunft. Frankfurt/M.: Insel, 1984.

[21] Gramsci, Antonio. Selections from the Prison Notebooks of Antonio Gramsci. Ed. and transl. by Quintin Hoare. London: Lawrence and Wishart, 1998.

[22] Arens, W. and Susan P. Montague, eds. The American Dimension: Cultural Myths and Social Realities. Sherman Oaks: Alfred, 1981. 